\title{
A brief statistical analysis of stomatology papers published in international journals by researchers from the mainland of China
}

- Based on Thomson Reuters' Journal Citation Reports for 2009

\author{
Yu-hua Zhang ${ }^{1 *}$, Yun-tao Pan ${ }^{1}$, Xiao Hong ${ }^{2}$ \\ ${ }^{1}$ Institute of Scientific and Technical Information of China, Beijing 100038, China; ${ }^{2}$ State Key Laboratory of Oral \\ Diseases, Sichuan University, Chengdu 610041, China
}

This paper has briefly analyzed the publication status of Chinese stomatology papers in 2009 with statistics from Journal Citation Reports ${ }^{\circledR}$ provided by Thomson Scientific. Only those papers with the first author coming from the mainland of China were included for calculations. We have found a significant increase in the number of SCIE-indexed papers, most of which were published by six dental institutions in China. Among all Chinese medical institutions, West China School of Stomatology Sichuan University is the first dental institution to enter the top-20 list with the most publications, and it also ranks the 9th in the number of outstanding articles. West China School of Stomatology Sichuan University and the Forth Military Medical University are the only two dental institutions in China which have published SCIE-indexed papers over a hundred. The former has published the most SCIE-indexed stomatology papers, while the latter has the highest average impact factor. As the laboratories and funds in China have close connections with various dental hospitals, the pratice of translational medicine in dentistry is fast and fluent.

Keywords: oral; dentistry; Journal Citation Reports; SCIE-indexed papers

International Journal of Oral Science (2011) 3: 1-6. doi: 10.4248/IJOS11003

\section{Introduction}

In this paper, we have briefly analyzed the publication status of Chinese scientific papers in 2009. Related statistics were derived from Web of Science provided by Thomson Scientific. Only those papers with the first author coming from the mainland of China were included for calculations [1-3].

*Correspondence: Yu-hua Zhang

Tel: 861058882537

E-mail: zyh@istic.ac.cn

Received 17 November 2010; Accepted 5 December 2010
Overall status

In 2009, there are 127532 papers indexed by the Science Citation Index-Expand (SCIE) database, of which 108805 were written by authors from the mainland of China. Five hundred and ninety three of the 108805 scientific papers were written by dental clinical and research institutions, accounting for half a percent of the total number, which includes 559 articles, 14 reviews and 11 letters. The average literature indices of these papers are as follows: 5.6 authors (4.7 for the national level), 2.5 institutions (2.0 for the national level), 28.1 references (26.7 for the national level), and an Immediacy Index 0.61 (0.77 for the national level). Compared 
with the statistics for 2006, the number of articles has increased by $382(227 \%)$, while the number of reviews has increased by $10(333 \%)$.

According to Journal Citation Reports (JCR) for 2009 at Web of Science, there are 64 dental journals indexed by SCIE with the statistical measures reported (Table 1).
These 64 journals have published a total of 6924 articles and reviews, 260 of which were written by Chinese authors, accounting for $3.76 \%$. Compared with 2006, the proportion of journals with the first author from the mainland of China has increased by $84 \%$, and the proportion of Chinese papers has increased by $1.4 \%$.

Table 1 The 64 dental journals indexed by SCIE with the statistical measures reported in JCR for 2009

\begin{tabular}{|c|c|c|c|c|c|c|c|c|}
\hline Abbreviated journal title & $\begin{array}{l}\text { Country/ } \\
\text { Territory }\end{array}$ & $\begin{array}{l}\text { Total } \\
\text { cites }\end{array}$ & $\begin{array}{l}\text { Impact } \\
\text { factor }\end{array}$ & $\begin{array}{l}\text { Immediacy } \\
\text { index }\end{array}$ & Articles & $\begin{array}{l}\text { Chinese } \\
\text { articles }\end{array}$ & References & $\begin{array}{c}\% \text { of } \\
\text { Chinese } \\
\text { articles }\end{array}$ \\
\hline Acta Odontol Scand & Norway & 2134 & 1.412 & 0.140 & 57 & 2 & 30.6 & 3.509 \\
\hline Am J Dent & USA & 1783 & 1.314 & 0.113 & 71 & 1 & 32.6 & 1.409 \\
\hline Am J Orthod Dentofac & USA & 7929 & 1.327 & 0.182 & 253 & 4 & 31.6 & 1.581 \\
\hline Angle Orthod & USA & 3178 & 0.937 & 0.153 & 170 & 9 & 26.1 & 5.294 \\
\hline Arch Oral Biol & UK & 4452 & 1.649 & 0.392 & 171 & 13 & 37.7 & 7.602 \\
\hline Aust Dent J & Australia & 1022 & 1.220 & 0.221 & 68 & 0 & 35.4 & 0.000 \\
\hline Brit Dent $\mathrm{J}$ & UK & 2950 & 1.089 & 0.522 & 136 & 1 & 23.1 & 0.735 \\
\hline Brit J Oral Max Surg & UK & 2475 & 1.327 & 0.210 & 162 & 12 & 12.0 & 7.407 \\
\hline Caries Res & Switzerland & 2904 & 2.462 & 0.581 & 62 & 0 & 29.2 & 0.000 \\
\hline Cleft Palate-Cran J & USA & 2301 & 0.884 & 0.113 & 97 & 4 & 26.1 & 4.124 \\
\hline Clin Implant Dent $\mathrm{R}$ & Canada & 1111 & 2.452 & 0.316 & 38 & 1 & 32.4 & 2.632 \\
\hline Clin Oral Implan Res & Denmark & 5416 & 2.920 & 0.314 & 188 & 7 & 37.9 & 3.723 \\
\hline Clin Oral Invest & Germany & 956 & 2.233 & 0.455 & 55 & 0 & 36.9 & 0.000 \\
\hline Community Dent Hlth & UK & 678 & 0.969 & 0.100 & 20 & 0 & 18.2 & 0.000 \\
\hline Community Dent Oral & Denmark & 2567 & 2.418 & 0.194 & 62 & 2 & 35.2 & 3.226 \\
\hline Cranio & USA & 430 & 0.412 & 0.500 & 8 & 0 & 35.1 & 0.000 \\
\hline Dent Mater & UK & 5661 & 2.882 & 0.457 & 208 & 7 & 32.2 & 3.365 \\
\hline Dent Mater J & Japan & 857 & 0.929 & 0.084 & 95 & 0 & 29.5 & 0.000 \\
\hline Dent Traumatol & Denmark & 1325 & 1.316 & 0.074 & 121 & 2 & 30.3 & 1.653 \\
\hline Dentomaxillofac Rad & UK & 1429 & 1.229 & 0.247 & 73 & 1 & 25.8 & 1.370 \\
\hline Eur J Dent Educ & USA & 356 & 1.024 & 0.250 & 44 & 0 & 21.8 & 0.000 \\
\hline Eur J Oral Sci & Denmark & 2340 & 1.956 & 0.159 & 107 & 4 & 34.2 & 3.738 \\
\hline Eur J Orthodont & UK & 2340 & 0.975 & 0.102 & 98 & 0 & 33.1 & 0.000 \\
\hline Gerodontology & USA & 465 & 1.014 & 0.045 & 44 & 0 & 27.7 & 0.000 \\
\hline Implant Dent & USA & 900 & 1.505 & 0.150 & 60 & 0 & 29.6 & 0.000 \\
\hline Int Dent $\mathrm{J}$ & UK & 1223 & 0.632 & 0.196 & 51 & 0 & 38.2 & 0.000 \\
\hline Int Endod J & UK & 3642 & 2.223 & 0.328 & 128 & 2 & 36.7 & 1.563 \\
\hline Int J Oral Max Impl & USA & 5440 & 1.978 & 0.056 & 143 & 4 & 37.1 & 2.797 \\
\hline Int J Oral Max Surg & UK & 4103 & 1.444 & 0.130 & 200 & 19 & 22.9 & 9.500 \\
\hline Int J Paediatr Dent & USA & 846 & 1.141 & 0.230 & 61 & 0 & 28.4 & 0.000 \\
\hline Int J Periodont Rest & USA & 1932 & 1.702 & 0.086 & 58 & 2 & 29.6 & 3.448 \\
\hline Int J Prosthodont & USA & 2318 & 1.227 & 0.111 & 99 & 3 & 18.9 & 3.030 \\
\hline
\end{tabular}


Cont. Table 1

\begin{tabular}{|c|c|c|c|c|c|c|c|c|}
\hline Abbreviated journal title & $\begin{array}{l}\text { Country/ } \\
\text { Territory }\end{array}$ & $\begin{array}{l}\text { Total } \\
\text { cites }\end{array}$ & $\begin{array}{l}\text { Impact } \\
\text { factor }\end{array}$ & $\begin{array}{l}\text { Immediacy } \\
\text { index }\end{array}$ & Articles & $\begin{array}{l}\text { Chinese } \\
\text { articles }\end{array}$ & References & $\begin{array}{c}\% \text { of } \\
\text { Chinese } \\
\text { articles }\end{array}$ \\
\hline J Adhes Dent & UK & 938 & 1.638 & 0.071 & 56 & 1 & 35.6 & 1.786 \\
\hline J Am Dent Assoc & USA & 4800 & 1.726 & 0.426 & 108 & 0 & 34.3 & 0.000 \\
\hline J Appl Oral Sci & Brazil & 201 & 0.386 & 0.092 & 109 & 0 & 26.8 & 0.000 \\
\hline J Can Dent Assoc & Canada & 929 & 0.959 & 0.182 & 44 & 0 & 25.7 & 0.000 \\
\hline J Clin Periodontol & Denmark & 7155 & 3.549 & 0.350 & 140 & 3 & 36.9 & 2.143 \\
\hline J Cranio Maxill Surg & UK & 1699 & 1.252 & 0.176 & 74 & 1 & 23.2 & 1.351 \\
\hline J Dent & UK & 3271 & 2.000 & 0.169 & 136 & 4 & 33.6 & 2.941 \\
\hline J Dent Educ & USA & 1747 & 1.087 & 1.362 & 127 & 0 & 23.3 & 0.000 \\
\hline J Dent Res & USA & 12340 & 3.458 & 0.302 & 172 & 6 & 39.5 & 3.488 \\
\hline J Dent Sci & $\begin{array}{l}\text { Chinese } \\
\text { Taipei }\end{array}$ & 16 & 0.107 & 0.000 & 28 & 0 & 32.9 & 0.000 \\
\hline J Endodont & USA & 7898 & 2.953 & 0.487 & 277 & 14 & 31.6 & 5.054 \\
\hline J Esthet Restor Dent & UK & 395 & 0.797 & 0.139 & 36 & 0 & 24.1 & 0.000 \\
\hline J Oral Maxil Surg & USA & 8986 & 1.580 & 0.229 & 424 & 29 & 26.1 & 6.840 \\
\hline J Oral Pathol Med & Denmark & 3198 & 2.144 & 0.385 & 117 & 14 & 40.0 & 11.966 \\
\hline J Oral Rehabil & UK & 3546 & 1.483 & 0.142 & 113 & 6 & 36.8 & 5.310 \\
\hline J Orofac Orthop & Germany & 388 & 0.890 & 0.086 & 35 & 0 & 36.8 & 0.000 \\
\hline $\mathrm{J}$ Orofac Pain & USA & 963 & 1.263 & 1.621 & 29 & 0 & 45.4 & 0.000 \\
\hline J Periodontal Res & Denmark & 2549 & 1.966 & 0.310 & 100 & 8 & 37.9 & 8.000 \\
\hline J Periodontol & USA & 10313 & 2.192 & 0.278 & 237 & 7 & 38.7 & 2.954 \\
\hline J Prosthet Dent & USA & 6680 & 1.215 & 0.119 & 101 & 2 & 25.4 & 1.980 \\
\hline J Public Health Dent & USA & 738 & 0.961 & 0.195 & 41 & 0 & 27.1 & 0.000 \\
\hline Odontology & Japan & 103 & 0.650 & 0.118 & 17 & 0 & 43.9 & 0.000 \\
\hline Oper Dent & USA & 2188 & 1.683 & 0.130 & 100 & 1 & 32.8 & 1.000 \\
\hline Oral Dis & Denmark & 1681 & 1.922 & 0.325 & 83 & 4 & 46.8 & 4.819 \\
\hline Oral Microbiol Immun & Denmark & 1973 & 2.336 & 0.386 & 83 & 1 & 36.6 & 1.205 \\
\hline Oral Oncol & UK & 3905 & 3.123 & 0.773 & 207 & 21 & 36.7 & 10.145 \\
\hline Oral Surg Oral Med O & USA & 10077 & 1.499 & 0.143 & 447 & 33 & 29.4 & 7.383 \\
\hline Orthod Craniofac Res & USA & 446 & 1.607 & 0.184 & 38 & 0 & 39.6 & 0.000 \\
\hline Periodontol 2000 & Denmark & 1760 & 3.027 & 1.474 & 38 & 0 & 114.1 & 0.000 \\
\hline Quintessence Int & USA & 1790 & 0.635 & 0.106 & 113 & 5 & 24.5 & 4.425 \\
\hline Rev Stomatol Chir & France & 250 & 0.349 & 0.031 & 64 & 0 & 12.9 & 0.000 \\
\hline Swed Dent J & Sweden & 639 & 0.927 & 0.045 & 22 & 0 & 25.8 & 0.000 \\
\hline
\end{tabular}

Sixteen of the 64 dental journals have an impact factor greater than 2, which have altogether published 2148 papers in 2009 (Table 1). Chinese authors have published 89 papers in 13 of the 16 journals, which account for $4.1 \%$ of the 2148 papers. However, Chinese researchers have only published four papers in J Clin Periodontol, a dental journal with the highest impact factor (IF). Chinese articles account for $2.14 \%$ of the 140 papers published by $J$ Clin Periodontol. When it comes to the dental journal with the highest total cites, $J$ Dent Res, 
Chinese authors have only published six papers, consisting $3.5 \%$ of the total amount.

Thirty eight of the 64 journals $(59.4 \%)$ have published papers with the first author from China. Of the 38 journals, two have published over ten Chinese papers, they are respectively $J$ Oral Pathol Med (14 Chinese papers, $11.97 \%$ of all the papers published in the journal) and Oral Oncol $(21,10.15 \%$ of all the papers published in the journal).

\section{Analysis of Chinese dental papers published in inter- national journals}

\section{Demographic and Institutional Distribution of Chinese Papers}

In 2009, 57 Chinese institutions have published scientific papers indexed by SCIE. These institutions distribute in 21 Chinese provinces and municipalities, seven of which have published papers over 20. Sichuan province stands on the top of the list (137 papers), which is sequentially followed by Shanxi province (105 papers), Hubei province (74 papers), Shanghai (70 papers), Beijing (62 papers), Guangdong province (57 papers) and Zhejiang province (26 papers). The other ten provinces and municipalities in China have not published papers in SCIE-indexed journals. China has approximately five hundred medical institutions which have published SCIE-indexed papers. Among these, West China School of Stomatology ranks the 9th in the number of outstanding articles among all Chinese medical institutions (outstanding articles refer to those with higher immediate citations than the average level of the same field). With respect to the total number of papers, West China
School of Stomatology is the first dental hospital to enter the top-20 list with the most publications.

The top six institutions which have published SCIEindexed papers over 30 are listed below (Table 2). What needs to be noted is that Sichuan University West China School of Stomatology and the Fourth Military Medical University are the only two dental institutions in China which have published SCIE-indexed papers over a hundred. The average statistical measures are shown in Table 3. Of all the six institutions, with respect to the number of references, immediate cites in 2009 and the number of reviews, West China School of Stomatology ranks first. When it comes to the average impact factor, the Forth Military Medical University tops the list.

Table 2 Chinese dental institutions which have published over 30 SCIE-indexed papers in 2009

\begin{tabular}{lc}
\hline \multicolumn{1}{c}{ Name of institution } & $\begin{array}{c}\text { No. of papers } \\
\text { published }\end{array}$ \\
\hline $\begin{array}{l}\text { Sichuan University, West China School } \\
\text { of Stomatology }\end{array}$ & 137 \\
$\begin{array}{l}\text { The Fourth Military Medical University, } \\
\text { School of Stomatology }\end{array}$ & 105 \\
$\begin{array}{l}\text { Wuhan University, School of Stomatology } \\
\text { Shanghai Jiaotong University, School of } \\
\text { Stomatology }\end{array}$ & 69 \\
$\begin{array}{l}\text { Beijing University, School of Stomatology } \\
\text { Sun Yet-sen University, Guanghua School } \\
\text { of Stomatology }\end{array}$ & 49 \\
\hline
\end{tabular}

Table 3 The six Chinese institutions which have published the most SCIE-indexed papers in 2009

\begin{tabular}{|c|c|c|c|c|c|c|c|c|}
\hline Name of Institution & Papers & Articles & Reviews & Authors & Institutions & $\begin{array}{l}\text { Impact } \\
\text { factor }\end{array}$ & References & $\begin{array}{c}\text { Times } \\
\text { cited }\end{array}$ \\
\hline $\begin{array}{l}\text { Sichuan University, West China School of } \\
\text { Stomatology }\end{array}$ & 137 & 133 & 4 & 6.3 & 2.4 & 2.076 & 33.5 & 0.83 \\
\hline $\begin{array}{l}\text { The Fourth Military Medical University, } \\
\text { School of Stomatology }\end{array}$ & 105 & 98 & 2 & 6.3 & 2.9 & 2.453 & 30.3 & 0.74 \\
\hline Wuhan University, School of Stomatology & 69 & 67 & 2 & 4.9 & 2.6 & 2.145 & 30.1 & 0.64 \\
\hline $\begin{array}{l}\text { Shanghai Jiao Tong University, School of } \\
\text { Stomatology }\end{array}$ & 63 & 60 & 1 & 6.0 & 2.6 & 2.056 & 26.4 & 0.45 \\
\hline Beijing University, School of Stomatology & 49 & 47 & 0 & 4.7 & 2.3 & 2.145 & 27.0 & 0.66 \\
\hline $\begin{array}{l}\text { Sun Yet-sen University, Guanghua School } \\
\text { of Stomatology }\end{array}$ & 32 & 31 & 1 & 5.4 & 2.4 & 2.339 & 28.6 & 0.58 \\
\hline
\end{tabular}

Notes: In this table "Papers" refers to all kinds of publications; "Articles" includes articles, letters and editorials; "Authors", "Institutions", "Impact factor" and "References" are averages. "Times cited" refers to the number of citations in 2009. 
These six dental institutions have rich medical and research resources. The research capacity of the six institutions is strong and research output has reacted in accordance. However, there are still a lot of dental institutions without papers indexed by SCIE.

\section{Subject Category Distribution of Chinese Papers}

Of the 174 SCI subject categories, Chinese papers are involved in 57 subjects, 16 subjects have published over five Chinese papers per subject, five of which have published over 30 Chinese papers per subject. The subject having published the most Chinese papers in 2009 is DENTISTRY with $44 \%$ (239) of all the papers published being Chinese papers. The SCIE subjects with the proportion of Chinese papers after DENTISTRY are listed in Table 4. It can be deduced that the scientific output of China has a wide distribution of subjects. A crosslink of diverse research fields is also obviously observed.

Table 4 SCIE subjects category distribution of Chinese papers for 2009

\begin{tabular}{cl}
\hline No. of papers & \multicolumn{1}{c}{ Subject category } \\
\hline 239 & Dentistry \\
43 & Medicine \\
41 & Oncology \\
36 & Engineering \\
34 & Biochemistry \& Molecular Biology \\
25 & Surgery \\
12 & Biotechnology \& Applied Microbiology \\
10 & Cell Biology \\
8 & Cell \& Tissue Engineering \\
8 & Chemistry \\
8 & Materials Science \\
8 & Pathology \\
6 & Anatomy \& Morphology \\
6 & Biochemical Research Methods \\
6 & Computer Science \\
\hline &
\end{tabular}

\section{Trends of Chinese Paper Publication}

In 2009, the 593 Chinese SCIE-indexed papers were distributed in 215 international journals, and only 260 of which were published in the 64 SCIE-indexed dental journals. This means that over a half of the 593 papers get published in non-dental journals. Therefore it can be classified as a diversified scientific research output. Seven SCIE indexed journals have published over ten Chinese papers, and Medical Hypotheses ranks first with 35 papers (see Table 5). The trend of Chinese paper publication can also be reflected in the 64 SCIE-indexed journals (see Table 6).

Table 5 SCIE-indexed journals with over 10 Chinese papers published

\begin{tabular}{cl}
\hline No. of papers & Abbreviated journal title \\
\hline 35 & Med Hypotheses \\
34 & Oral Surg Oral Med O \\
29 & J Oral Maxil Surg \\
28 & Oral Oncol \\
19 & Int J Oral Max Surg \\
14 & J Endodont \\
14 & J Oral Pathol Med \\
\hline
\end{tabular}

Table 6 Publication trends of Chinese papers

\begin{tabular}{lcrc}
\hline Country & $\begin{array}{c}\text { No. of } \\
\text { Journals }\end{array}$ & $\begin{array}{c}\text { Chinese } \\
\text { papers }\end{array}$ & $\begin{array}{c}\text { \% of Chinese } \\
\text { papers }\end{array}$ \\
\hline USA & 15 & 124 & 47.69 \\
UK & 12 & 88 & 33.85 \\
Denmark & 9 & 45 & 17.31 \\
Norway & 1 & 2 & 0.77 \\
Canada & 1 & 1 & 0.38 \\
Total & 38 & 260 & 100.00 \\
\hline
\end{tabular}

These 260 papers are scattered in 38 dental journals edited by five countries; nearly a half of these papers were published by American journals. There are 25 American journals, 16 British journals and ten Danish journals indexed by SCIE. Chinese authors have published 124 papers in 15 of the 25 American journals; 88 papers in 16 British journals and 45 papers in 9 Danish journals. The number of Chinese papers published in SCIE-indexed Norwegian and Canadian journals was, respectively, two and one. All of the reported Chinese papers were written in English. Therefore, there is a trend for Chinese authors to publish their research findings in American and British journals.

\section{Conclusions}

There is a significant increase in the number of scientific papers published by Chinese dental institutions in 2009 compared to previous years. This increase can be largely attributed to the contributions of a number of 
basic research laboratories established in China. This can be interpreted as another example of the fact that only scientific research is able to produce scientific papers continuously. These laboratories have produced 146 of all the 573 original articles and reviews, accounting for a little over a quarter $(25.5 \%)$ of the total amount. State Key Laboratory of Oral Diseases located at West China School of Stomatology contributed 75 papers (accounting for $54.7 \%$ of the total SCIE papers published by the School), Key Laboratory of Oral Biomedical Engineering located at Wuhan University contributed 45 papers (65.2\%), and Shanghai Ninth People's Hospital Affiliated Shanghai Jiaotong University School of Medicine has contributed 23 papers $(36.5 \%)$.

What is worth mentioning is that these laboratories have close connections with various dental hospitals in China. Therefore, the transformation from findings of basic scientific research into clinical practice is fast and fluent.

The increase of scientific papers published is closely related to government's support of scientific research in dentistry. Taking 2009 as an example, 350 of the 593 Chinese SCIE indexed papers were supported by various foundations and government grants. Two hundred and one papers were supported by national grants. Various statistical indices of SCIE indexed Chinese papers have risen to different extent in 2009.

The SCIE has classified 174 subject categories altogether, 57 of which have involved Chinese papers and Chinese authors have published over 5 papers per subject in 16 subjects. This indicates that dental research in China is inter-linked with a variety of different fields, e.g. materialogy, cell biology etc. (see Table 4).

Five Chinese papers have an immediacy index greater than 5, four of which come from Sichuan University West China School of Stomatology, while the other comes from The Fourth Military Medical University School of
Dentistry. The paper with the highest immediacy index of 12 is published in Cancer Letters by State Key Laboratory of Oral Diseases located at West China School of Stomatology Sichuan University.

The number of dental institutions having published SCIE-indexed papers has increased also. In 2006, only 24 dental institutions (Name of the institution contains STOMATOL or ORAL) had published SCIE indexed papers. This number has gradually increased to 62 in 2009. At the same time, the number of international papers published by those 24 dental institutions has increased too.

It is estimated that Chinese scientific research output will further increase in the future. What needs to be noted is that the mainland of China already has an English dental journal indexed in the SCIE/PubMed databases since 2009 - International Journal of Oral Science, which adds to another wonderful platform for publication of findings of scientific studies. However, there is still a long way to go to enhance the influence of Chinese scientific papers as well as Chinese scientific journals.

\section{Reference}

1 Thomson Scientific. ISI Web of Knowledge: Web of Science (DB/OL). on World Wide Web http://portal. isiknowledge.com/ web of science. [accessed on 9/10/2010].

2 Thomson Scientific. ISI Web of Knowledge (DB/OL), journal citation reports 2009. on World Wide Web http://portal. isiknowledge.com/journal citation reports. [accessed on $9 / 10 /$ 2010].

3 Thomson Scientific. Web of Science (DB/OL), journal selection process. on World Wide Web http://www. Thomson scientific.com.cn/web of science (DB/OL), Journal selection process. [accessed on $9 / 10 / 2010$ ]. 